\title{
Empowering Student Entrepreneurship through Creative Thinking: A Sustainable Innovation towards Industrial Revolution 4.0
}

\author{
*Corresponding Author \\ Iwan Irwansyah

\section{Article History} \\ Received: 11.11.2019 \\ Accepted: 18.11 .2019 \\ Published: 30.11 .2019
}

Iwan Irwansyah, S.Pd.I, MA*

STIAMI- Institute of Social Sciences and Management, Jl. Kartini No 10, Margahayu, Kota Bekasi, Indonesia

\begin{abstract}
This research is intended to answer the questions on how universities implement Entrepreneurship courses to students and how universities can instill and develop student creativity to change the mindset from being an employee to an entrepreneur. This study employed a phenomenological approach of a qualitative research design since it can describe the meaning for several individuals of their lived experiences of a concept or a phenomenon. For this study, the researcher interviewed university students to gain information about their experiences in the process of learning how to become entrepreneurs and how the Entrepreneurship Lecture is implemented in their colleges. The researcher also interviewed Student Affairs Managers to dig deeper their perspectives on student entrepreneurship. In order to make this research more objective, the researcher also interviewed Entrepreneurship Lecturers to gain information about how the entrepreneurship lecture should be conducted. The research proved that most of the universities still teach Entrepreneurship theoretically. There are also still limited universities which provide incubator facilities for the start up and most of the students still have the mindset of becoming employees not entrepreneurs so they haven't optimized the creative thinking. This mindset needs to be changed. For future research, the researcher recommends to dig deeper the issues on how entrepreneurship program is developed in universities with different approaches to be adopted.
\end{abstract}

Keywords: Student Entrepreneurship, Creative Thinking, Sustainable Innovation.

\section{INTRODUCTION}

The progress of a nation is very dependent on the development of entrepreneurship in the country, because entrepreneurship is a key factor in the success of a country's economy. Educating the entrepreneurial community is the same as preventing people from becoming unemployed, which in turn will reduce poverty. Reducing poverty will bring a country to prosperity, because the formulation of a prosperous country, if $2 \%$ of the population are entrepreneurs / entrepreneurs. In 2009, the number of entrepreneurs in Indonesia was 450,000 people, or around $0.18 \%$ of Indonesia's total population of 250 million. It is clear that Indonesia is not yet a prosperous country, compared to the United States with an entrepreneurship of 7.2\%, while Japan and Korea are 5\%. The condition in Indonesia is quite good because the data on the number of Indonesian entrepreneurs in 2012 increased to $1.55 \%$ of the total population [1].

So far, most universities only provide theories about entrepreneurship education compared to increasing practice. As a result, the percentage of applications or application of practical knowledge in the business world is still very minimal. The lack of knowledge makes them less ready to apply their knowledge in real life practice. In supporting the birth of leading entrepreneurs from campus, the entrepreneurship lecture method is focused on motivating students to choose entrepreneurship as their life career, in addition to understanding entrepreneurial disciplines. Lectures must be designed in such a way that a student is ready to become an entrepreneur. One of the most basic characteristics of entrepreneurship is creative and innovative, and the ability to take advantage of opportunities and solve problems. Therefore, understanding and mastery of methods to develop creativity is the basis of all entrepreneurship lectures.

Entrepreneurship is encouraged because employment is unable to accommodate university graduates. Because, most students hope that when they graduate, they can immediately work. However, the reality is that not all students who graduate directly

Copyright @ 2019: This is an open-access article distributed under the terms of the Creative Commons Attribution license which permits unrestricted use, distribution, and reproduction in any medium for non commercial use (NonCommercial, or CC-BY-NC) provided the original author and source are credited. 
get a job. Even though every year, universities continue to produce hundreds of graduates. This is what ultimately led to higher educated unemployment rates. The problem of high educated unemployment is now a serious phenomenon to be addressed. Based on BPS data, the number of labor force in February 2018 was 133.94 million people, an increase of 2.39 million compared to February 2017. The components forming the labor force are working population and unemployment. In February 2018, 127.07 million people were employed while 6.87 million people were unemployed. Compared to a year ago, the number of working people increased by 2.53 million while unemployment decreased by 140 thousand. The Open Unemployment Rate (TPT) is an indicator that can be used to measure the level of labor supply that is not used or not absorbed by the labor market.

The open unemployment rate in February 2017 was 5.33 percent, down to 5.13 percent in February 2018. Judging from the level of education in February 2018, the open unemployment rate for Vocational High Schools was the highest among other education levels, which was 8.92 percent. The next highest open unemployment is in Diploma I / II / III of 7.92 percent which is not absorbed especially at the level of vocational education and Diploma I / II / III. Those with low education tend to be willing to accept any kind of work. It can be seen from the level of open unemployment in which the lowest is elementary school. It serves as the lowest among all education levels, namely 2.67 percent [2].

The formation of the young generation to think of creating (create), is an initial solution in the formation of a superior generation to overcome the economic problems that exist in the community. In the young generation, there must be a lot of insight and experience to be developed in the business world in order to grow the native entrepreneurs of the nation or indigenous entrepreneurs who are competent and able to improve the nation's economy later. However, entrepreneurship cannot automatically just be like that. There are a series of formation that must be done, including building a mindset. Unfortunately, currently not many universities have study programs, majors or entrepreneurship or business courses. The Ministry of Education and Culture has developed programs in every tertiary institution to have entrepreneurship Education since 2010. Higher education institutions are required to be able to produce creative and innovative students.

However, until now, there are still many students who have the mindset of wanting to become employees rather than employers for various reasons, including being a much better employee because they will get a fixed salary. Meanwhile, if we become entrepreneurs must have large capital, we must also pay employees. It is these various thoughts which then hinder the birth of young entrepreneurs in Indonesia. For this reason, this research is intended to answer the question how universities implement Entrepreneurship courses to students and how universities can instill and develop student creativity to change the mindset from being an employee to an entrepreneur.

\section{LITERATURE REVIEW \\ Student Entrepreneurship}

A change in the economy has been identified recently, moving from knowledge based activities to creativity, innovation, entrepreneurship and imagination [3, [4]. Universities are now tasked with promoting regional development and economic growth [5]. They are now providing entrepreneurship education and offering incubator facilities, becoming more and more "entrepreneurial universities" [6, 7]. Creative Thinking Gary Klukken et al., [8] reads: "A lack of creativity is clearly problematic in a rapidly changing, technologically oriented world where generating new ideas is essential to survival."

Henderson and Robertson said "young people are likely to experience a portfolio career consisting of periods of paid employment, non-work, and self employment" [9]. Additionally, according to the latest report from the Kauffman Foundation [10], it is a global phenomenon: "Among young people, the word has gone out that those without self-starting skills may be at a permanent disadvantage."

For the former, Entrepreneurship refers to the first-stage of the founding of a business and connotes the classic Silicon Valley notion of a start-up and the innovative spirit required to launch one [11]. For the latter, Entrepreneurship is seen as a process of change for the venture and the entrepreneur: "while Entrepreneurship is to do with a process of change, emergence and the creation of new value, it is also a process of change and creation for the entrepreneur". Schumpeter, as noted by Peters and Besley [12], provided an account of entrepreneurship and the role and significance of the entrepreneur who, through innovation, led the gales of "creative destruction", making old ideas, technologies and skills obsolete, serving as the source of progress and improvement in the standard of living. For Schumpeter, the entrepreneur is the individual carrying out new combinations, introducing new products or processes, identifying new export markets or sources of supply, even creating new types of organization.

Leadbeater and Oakley [13] call the knowledge entrepreneurship a structured activity, instead of merely a flash of individual genius, built in six stages: creation, sensing, packaging, mobilizing, acting and exiting. Thus, the basic unit of entrepreneurship is not the individual but teams or partnerships providing tight networks in distinctive industry clusters. Sternberg [14] defines entrepreneurship as a form of creativity - labeled as business or entrepreneurial creativity - because new businesses are often original. Lee et al., [15] divide academic approaches on entrepreneurship into two major categories: the first one on entrepreneurs (and the reasons why an individual decides to become one and start a new firm) and the second one on regional variations in firm 
formation (looking at structural variations in geographical areas). According to Thompson [16] entrepreneurial activity depends on the process of innovation following creativity, not on creativity alone.

Centobelli et al., [17] provide a useful organizing framework. Seven key skills that entrepreneurs needed were denoted: Personal skills; Innovative skills; Financial skills; Organizational skills; Strategic skills; Relational skills (systemic grasp of the link between a startup and its surrounding ecosystem); and Reputational skills (building trust and mutual understanding) as shown in Figure-1 below.

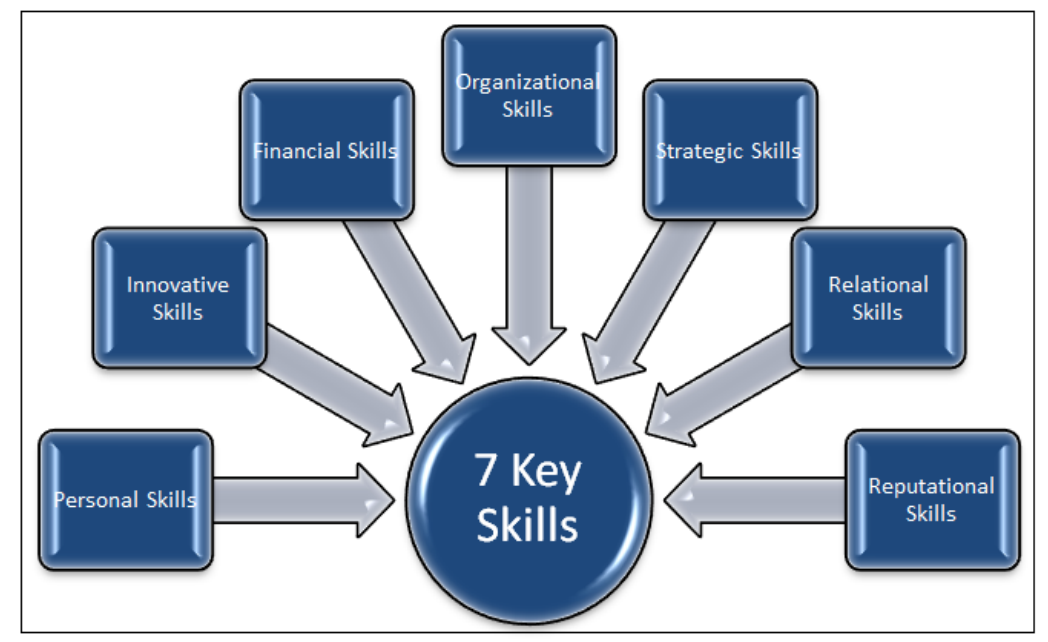

Fig-1: 7 Key Skills

Resource: Centobelli et al., [17]

\section{Creativity and Entrepreneurship}

Creativity is a word that affects people and evokes extraordinary. It refers to the first and the new one. "Creativity is the ability to create new ideas" [18]. One of the important resources of an enterprise is the creative abilities of people. Individuals with creative ability produce original ideas [19]. Creativity is the source of innovation, and it can lead to generate new business and improve products to enable enterprises possess more competitive capability [20]. Creativity is not only important for enterprises, but also, or to play an important role when entrepreneurs make strategic decisions throughout entire business creation process [20, 21]. In brief, creativity is a start point and achieve success main factor for create new business [22].

Lee et al., [15] note that entrepreneurial activity not only requires both a supportive and productive business climate but that it also needs an environment where creativity and innovation can flourish. Having a strong and diverse knowledge base, well developed business and social networks and an ability to identify opportunities also contribute to successful entrepreneurial behavior $[23,20,24,25]$.

Fillis and Rentschler [26] view creativity as being able to do imaginative and non-routine things while also building on tradition to achieve profitable outcomes. Hunter et al., [27] view creativity as emerging from an interaction between the individual and the situation, facilitated by an appropriate environment or climate. Creativity has been linked to genius and in science, business and art, a number of individuals have attained heroic status through their creative philosophies, discoveries, practices and products [28, 29].

Entrepreneurial creativity, however, exists before, during and after the lifetime of a particular business since it is shaped in part by the social world and by the individual decision maker [26]. There are also a number of other contributing internal and external impacting factors: entrepreneurial creativity requires a combination of intrinsic motivation and certain kinds of extrinsic motivation - a motivational synergy that results when strong levels of personal interest and involvement are combined with the promise of rewards that confirm competence, support skill development, and enable future achievement [30].

One cannot think creatively unless one has the knowledge with which to think creatively. Creativity represents a balance between knowledge and freeing oneself of that knowledge' as stated by Johnson-Laird [31] cited in Sternberg [32]. According to John Hagel III, we are in the midst of a vast global flow of ideas, innovations, and opportunities for profit through collaboration [33]. Producing innovative products/services in a sustainable development requires a sustainable innovation. Based on the scheme of sustainable development parts, UCN 2006 have identified sustainable innovation like in Figure-2 below. 


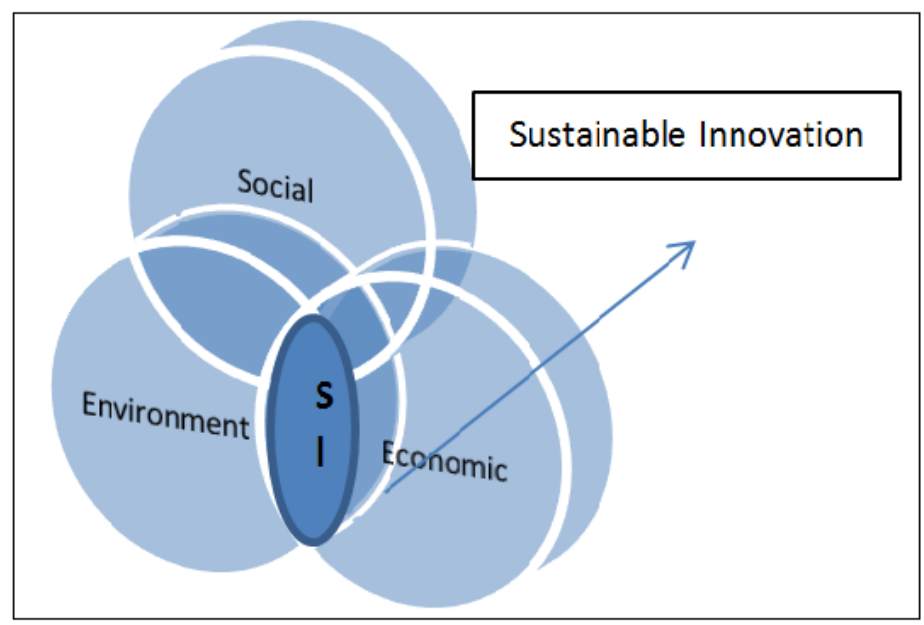

Fig-2: Sustainable Innovation

Resource: Sustainable Innovation - based on UCN 2006 Source

\section{Characteristics of Creative Individuals}

Creativity occurs at the end of a particular type of personality. Flexibility, sensitivity, tolerance, responsibility, autonomy and positive self-criticism are among the characteristics of creative personality [34]. Creative individuals do not like ambiguity, even alternatives do not tolerate, but there is a desire to see that anything can be combined with something else. At the same time, creative individuals are unsatisfied [35]. Yildirim [36] states the attitudes necessary for the development of creative thinking in the following way [36]: Self-confidence is high, Perfectionism, Everything is black-and-white, White, Having sense of humor, and Using imagination. Whereas Perkins [37] and Aktan Doganay [38] stated that Creativity requires intense desire and effort, Creativity requires intrinsic motivation rather than externally motivated, Creativity requires reshaping of thoughts, Creativity can sometimes occur at the end of intense work, at the moment when the mind is free, and Creativity is the center of mind. It requires working at the very tip.

Study of the relationship between creativity and personality tends to take one of three routes: explaining creativity by utilizing personality theories; examining the personality and biographical characteristics of well known creative individuals and their activities in different fields; and focusing on a small number of particular personality dimensions [39]. Barron and Harrington [40], for example, identified the following creative characteristics following a fifteen year long research program:

"...a fairly stable set of core characteristics (e.g. high valuation of aesthetic qualities in experience, broad interests, attraction to complexity, high energy, independence of judgement, autonomy, intuition, self-confidence, ability to resolve or accommodate apparently opposite or conflicting traits in one's self concept, and finally, a firm sense of self as 'creative') continued to emerge as correlates of creative achievement and activity in many domains" [40].

The personality of an individual consists of a unique pattern of traits which ensures that each individual differs from another. Behavior traits consist of aptitudes, interests, attitudes, and temperamental qualities. Creative personality is determined by the trait patterns which shape the characteristics of creative persons [41]. Positive personality traits of creative individuals include high levels of energy, attraction towards complex and novel phenomena, openness to ambiguity, willingness to be open-minded and being persistent in adverse conditions $[42,43]$. These factors are also located within the entrepreneurial personality.

\section{Sustainable Innovation for towards Industrial Revolution 4.0}

The innovation process is complex because it typically deals with a large number of interconnected factors that impact, or are impacted by, the other factors [44]. Innovation is a search process characterized by less regularity in its outcome. Production and innovation are interdependent [45].

An innovative process is the adoption of a new process or a new machine, by the organization, to facilitate the production of goods and services, to obtain the best results from fewer resources in an efficient way and to make the organisation to function in the best way. The innovative process became sustainable when the organisation achieves this improvement by the integration of economic, environmental and social concerns [46]. Harmony between the three pillars of sustainable development in innovation process is the best choice in terms of innovation. We can call it "sustainable innovation", which is distinguished from an ordinary innovation by bounding it to the constraints of society, environment and economy. Sustainable innovation is about using innovation to reduce energy consumption, social issues, improve environmental performance and it is a determinant key of economic performance and to our ability to keep innovating. Innovation should be created by taking into consideration the efforts to achieve the goals of sustainable development [47].

The relationship between entrepreneurship and sustainable development has been addressed by various streams of thought and literature such as ecopreneurship, social entrepreneurship, sustainable entrepreneurship and, in an indirect way also, institutional 
entrepreneurship. Furthermore, the notion of sustainable entrepreneurship has been raised more recently to address the contribution of entrepreneurial activities to sustainable development in a more comprehensive way. Such an ambitious approach of entrepreneurship that attempts not only to contribute to sustainable development of the organization itself, but also to create an increasingly large contribution of the organization to sustainable development of the market and society as a whole, requires substantial sustainability innovations [48]. Sustainable entrepreneurship is in essence the realization of sustainability innovations aimed at the mass market and providing benefit to the larger part of society.

The term 'sustainable entrepreneurship' essentially brings many of the above phenomena together and combines two words, sustainability and entrepreneurship. Sustainable entrepreneurship is characterized by some fundamental aspects of entrepreneurial activities which are less oriented towards management systems or technical procedures, and focus more on the personal initiative and skills of the entrepreneurial person or team to realize large-scale market success and societal change with environmental or societal innovations [48].

\section{Research Methods}

In this research, a qualitative research method is applied. the purpose of qualitative research is not formulating general statements but exploring specific social contexts to achieve better understanding of specified social settings Patton [49] as quoted in Crabtree \& Miller [50]. That is why the qualitative sample is selected purposefully and case study approach was adopted in this research.

The researcher employed a phenomenological approach as stated by Creswell that a phenomenological study "describes the meaning for several individuals of their lived experiences of a concept or a phenomenon" [51]. The purpose of the phenomenological method is to "reduce individual experiences with a phenomenon to a description of the universal essence". To achieve this goal, a researcher will usually identify a phenomenon for study [51]. Data collection takes place through in-depth interviews and multiple interviews [51]. Other forms of data, collected through observation or reviews of journals and art, can be included as well [51]. The interviews lasted for 45 minutes to 1 hour for every participant and we used semi structured interview since it can direct the interview more closely, to have a pre-determined set of questions while simultaneously allowing the interviewees sufficient flexibility to shape the flow of information given [52].

For this study, the researcher interviewed 8 university students to gain information about their experiences in the process of learning how to become entrepreneurs and how the Entrepreneurship Lecture is implemented in their colleges. The researcher also interviewed 2 Student Affairs Managers to dig deeper their perspectives on student entrepreneurship. In order to make this research more objective, the researcher also interviewed 4 Entrepreneurship Lecturers to gain information about how the entrepreneurship lecture should be conducted.

\section{RESEARCh Findings AND Discussion}

From the interviews with 8 students, the data were obtained that 6 people said that currently entrepreneurship courses already exist in each faculty. Students must take this course because it is a compulsory subject. On one hand, students feel there is a renewal with the compulsory entrepreneurship course. But on the other hand, students have not seen any difference between this subject and the other subjects. Of the 8 students interviewed, 6 said that this course was held like any other courses. The lecturer teaches for 2 hours in the classroom with the lecturing method, and discussion. Of the 14 sessions given each semester, there was no activity (project) assigned by the lecturer to students, so the students felt that this course was only theoretical subject and did not provide enlightenment and guidance to students to start a business.

Meanwhile, of the 8 students, there were only 2 who said that the entrepreneurship course was conducted very interestingly. Lecturers did not only teach the materials in the classroom, but also gave group assignments to students to optimize their creative thinking so they could run the start-ups. "We are given guidance starting from how we have to optimize our creative thinking so that new ideas emerge, because business ideally should be something original." This is in accordance with the statement of Sternberg [14] which defines entrepreneurship as a form of creativity - labeled as business or entrepreneurial creativity - because new businesses. On our campus is also a special venue that fosters new start-ups and offers incubator facilities. This is very helpful for students who are just starting their business, so that eventually they will become Entrepreneurial Universities, as stated by Politis, Winborg, \& Dahlstrand [6] and Rasmussen \& Sørheim [7].

For the interview with 4 Entrepreneurship lecturers, researchers defined 2 lecturers from private universities of the medium category and 2 lecturers who taught at private universities of the large category and were quite expensive. It turned out that their answers were far different. Lecturers from large category universities said that at present the university has required every student to take entrepreneurship courses. This is a subject that is given once a week for 2.5 hours. The lecturer teaching this subject must be a lecturer who has an entrepreneurial background and still actively runs a business. The learning system was 30\% theory and $70 \%$ practice in the form of group assignments where students were asked to collaborate and started a business concept. The biggest 
point in assessment was creative thinking because that was where the initial business ideas emerge that could be realized in the form of a business.

When asked if there had been complaints from students regarding the task of starting this business, bearing in mind that this required, the 2 lecturers said that so far there had never been any complaints because we always emphasized to students that to start a business there was no need to prepare a big amount of budget.

"By optimizing creative thinking, we can anticipate that business can be started even with limited budget, and in the teaching and learning process, lecturers always instill 7 key skills for an entrepreneur, namely: personal skills, innovative skills, organizational skills, strategic skills, relational skills and reputational skills." This is in line with the statement of Centobelli et al., [17].

Meanwhile, interviews with 2 lecturers from private universities in the medium category, obtained data that the entrepreneurship courses at their universities are taught by full time lecturers and not practitioners with a percentage of $70 \%$ theory and $30 \%$ practice. When asked in what form lecturers assign the task to practice, the two lecturers answered that practical tasks were group assignments where students had to make a business concept of what they were going to run and they had to present it in class. There were no assignments to the field because basically the entrepreneurship course given was just a pilot course. When asked whether there were incubator facilities for student start ups, the two lecturers answered that there was already a discourse to establish incubator facilities but there were still many problems, including supervisory, finding, product distribution and others.

The researcher also interviewed 4 student affairs managers, consisting of 2 large university managers and 2 medium category university managers and resulted in different answers. Two large university managers said that when it was decided that the university should provide compulsory entrepreneurship courses, we immediately built a system that not only held lectures, but also a comprehensive Entrepreneurship program, from start up coaching, incubator facilities to partnerships with the industrial sector . Thus students not only learn about theory, but also learn how to start a business from scratch.

"We not only equip students with technical knowledge (hard skills) but also non-technical knowledge (soft skills) primarily related to character because creative individuals must have positive characters such as dynamic, energetic, high level of energy, openness, open minded, persistent, patient" [42, 43].

Meanwhile 2 managers from medium universities showed that currently entrepreneurship courses have been held as well as other subjects. The teaching and learning system is the same. However, our lecturers ask to give group assignments to students to create business concepts. We have not yet started providing incubator facilities, but there are plans to establish it. For the time being, indeed, we depend a lot on lecturers who teach to be able to help students expand cooperation links with the industrial sectors so that the students can learn directly from the entrepreneurs. When asked whether the lecturers who teach must also be those with a business background, the two managers answered that ideally it is like that, but currently due to the limitations of lecturers, we only assign full time lecturers to teach entrepreneurship courses. In our opinion it does not matter, as long as the lecturer can facilitate students with company visits and establishing partnership with the industrial sectors.

\section{CONCLUSION}

From the findings described above, it can be concluded that most of the universities still teach Entrepreneurship with more theoretical than practical knowledge. There are still limited universities which provide incubator facilities for the start up, and most of the students still think that to become an entrepreneur, one must have a lot of funds. This mindset needs to be changed. For future research, the researcher recommends to dig deeper the issues on how entrepreneurship program is developed in universities with different approaches to be adopted.

\section{ACKNOWLEDGEMENT}

The researcher would like to thank STIAMI Institute of Social Sciences which has granted the research including the publication.

\section{REFERENCES}

1. https://media.neliti.com/media/publications/259420-motivasi-entrepreneurship-pada-mahasiswa-2f47bbc8.pdf

2. BPS Berita Resmi Statistik. (2018). Keadaan Ketenagakerjaan Indonesia Februari 2018 No. 42/05/Th. XXI, 07 Mei 2018).

3. Van den Broeck, H., Cools, E., \& Maenhout, T. (2008). A Case Study of Arteconomy-Building a bridge between art and enterprise: Belgian businesses stimulate creativity and innovation through art. Journal of Management \& Organization, 14(5), 573-587.

4. Oke, A., Munshi, N., \& Walumbwa, F. O. (2009). The influence of leadership on innovation processes and activities. Organizational Dynamics, 38(1), 64-72.

5. Rothaermel, F. T., Agung, S. D., \& Jiang, L. (2007). University entrepreneurship: a taxonomy of the literature. Industrial and corporate change, 16(4), 691-791. 
6. Politis, D., Winborg, J., \& Dahlstrand, Å. L. (2012). Exploring the resource logic of student entrepreneurs. International Small Business Journal, 30(6), 659-683.

7. Rasmussen, E. A., \& Sørheim, R. (2006). Action-based entrepreneurship education. Technovation, 26(2), 185-194.

8. Klukken, P. G., Parsons, J. R., \& Columbus, P. J. (1997). The creative experience in engineering practice: Implications for engineering education. Journal of Engineering Education, 86(2), 133-138.

9. Henderson, R., \& Robertson, M. (2000). Who wants to be an entrepreneur? Young adult attitudes to entrepreneurship as a career. Career development international, 5(6), 279-287.

10. Kauffman Foundation. (2013). Entrepreneurship Education Comes of Age on Campus.

11. Tjan, A. K., Harrington, R. J., \& Hsieh, T. Y. (2012). Heart, smarts, guts, and luck: what it takes to be an entrepreneur and build a great business. Harvard Business Press.

12. Peters, M. A., \& Besley, T. (2008). Academic entrepreneurship and the creative economy. Thesis Eleven, 94(1), 88-105.

13. Leadbeater, C., \& Oakley, K. (2001). Surfing the long wave: Knowledge entrepreneurship in Britain. Demos.

14. Sternberg, R. J. E. (1988). The Nature of Creativity: Contemporary Psychological Perspectives. Cambridge: Cambridge University Press.

15. Lee, S. Y., Florida, R., \& Acs, Z. (2004). Creativity and entrepreneurship: A regional analysis of new firm formation. Regional studies, 38(8), 879-891.

16. Thompson J. L. (2001). Strategic Management. Canada: Thomson Learning.

17. Centobelli, P., Cerchione, R., \& Esposito, E. (2017). Knowledge management in startups: Systematic literature review and future research agenda. Sustainability, 9(3), 361.

18. Barker, A. (2002). "Yenilikçiliğin Simyası", (Çev: Ahmet Kardam), Türkiye Metal Sanayicileri Sendikası, İstanbul, 23.

19. Bassett-Jones, N. (2005). The paradox of diversity management, creativity and innovation. Creativity and innovation management, 14(2), 169-175.

20. Ko, S., \& Butler, J. E. (2007). Creativity: A key link to entrepreneurial behavior. Business Horizons, 50(5):365-372.

21. Argyris, C. (1990). Overcoming organizational defenses, New Jersey: Prentice Hall.

22. Kruger, M. E., Millard, S. M., \& Pretorius, M. (2005). Creativity, innovation and implementation: Management experience, venture size, life cycle stage, race and gender as moderators. South African Journal of Business Management, 36(4), 55-68.

23. Harryson, S.J. (2008). "Entrepreneurship through relationships: navigating from creativity to commercialisation", $R \& D$ Management, Vol.38, No.3, pp.290-310.

24. Kijkuit, B., \& van den Ende, J. (2007). The organizational life of an idea: Integrating social network, creativity and decisionmaking perspectives. Journal of Management Studies, 44(6), 863-882.

25. Rosa, J. A., Qualls, W. J., \& Fuentas, C. (2008). Involving mind, body and friends: management that engenders creativity. Journal of Business Research, 61, 631-639.

26. Fillis, I., \& Rentschler, R. (2006). Creative Marketing: An Extended Metaphor for Marketing in a New Age, Palgrave Macmillan, Basingstoke.

27. Hunter, S. T., Bedell, K. E., \& Mumford, M. D. (2007). Climate for creativity: a quantitative review. Creativity Research Journal, 19(1), 69-90.

28. Puccio, G. J. (1991). William Duff's Eighteenth Century Examination of Original Genius and Its Relationship to Contemporary Creativity Research. Journal of Creative Behavior, 25(1), 1-10.

29. Eysenck, H. J. (2008). Genius: The Natural History of Creativity. Cambridge University Press, Cambridge.

30. Amabile, T. (1997). Entrepreneurial creativity through motivational synergy. Journal of Creative Behavior, 31(1), 18-26.

31. Johnson-Laird, P. N. (1988). The computer and the mind: An introduction to cognitive science. Harvard University Press.

32. Sternberg, R. J. (2012). The Assessment of Creativity: An Investment-based Approach. Creativity Research Journal, 24(1): 312.

33. Isaac, G., Levy, J., \& Ognits, A. (2012). The benefits of the new economy: resolving the global economic crisis through mutual guarantee. Laitman Kabbalah Publishers.

34. Sipahi, E. (2007). Creativity and the Importance of Business Management. August 2017.

35. McCare, R. R. (1987). Creativity, divergent thinking and openness to experience. Journal of Personality and Social Psychology, 1258-1265.

36. Yildirim. (1998). Yaratıcılık ve Yenilik, Sistem Yayıncılık Geliştiren Kitaplar Dizisi, İstanbul.

37. Perkins, J. R. (1991). Scholarship and the academic dean. Willey Online Library.

38. Doğanay, A. (2002). Yaratıcı Öğrenme, (Editör: Şımşek, A.), Sınıfta Demokrasi (3.Baskı), Eğitim-Sen Yayınları, Ankara.

39. Woodman, R. W., \& Schoenfeldt, L. F. (1990). An interactionist model of creative behavior. Journal of Creative Behaviour, 24(4), 279-290.

40. Barron, F., \& Harrington, D. M. (1981). "Creativity, intelligence, and personality”, in Porter, L.W., \& Rosenzweig, M. R. (eds.), Annual Review of Psychology, 32, 439-476.

41. Guilford, J. P. (1950). "Creativity”. American Psychologist, 5, 444.

42. Mintzberg, H., Raisinghani, D., \& Theoret, A. (1976). The structure of'unstructured'decision processes. Administrative science quarterly, 21(2):246-275.

43. Feist, G. J. (1999). "The Influence of Personality on Artistic and Scientific Creativity", in Sternberg, R. J. (Ed.), Handbook of Creativity, Cambridge University Press, Cambridge, 273-296. 
44. Hall, J., Matos, S., \& Silvestre, B. (2012). Understanding why firms should invest in sustainable supply chains: a complexity approach. International journal of production research, 50(5), 1332-1348.

45. Lundvall, B. Å. (1985). Product Innovation and User-Producer Interaction, Aalborg: Aalborg University Press.

46. Fortkamp, U., \& Staffas, L. (2012). Integration of sustainability aspects in innovation process. IVL. Swedish Environmental Research Institution Ltd IVL report B2025.

47. Cornescu, V., \& Adam, C. R. (2013). The consumer resistance behavior towards innovation. Procedia Economics and Finance, 6, 457-465.

48. Schaltegger, S., \& Wagner, M. (2011). Sustainable entrepreneurship and sustainability innovation: categories and interactions. Business strategy and the environment, 20(4), 222-237.

49. Patton, M. Q. (1990). Qualitative evaluation and research methods (2nd ed.). Newbury Park, CA: Sage, 532.

50. Crabtree, B. F., \& Miller, W. L. (1992). Depth Interviewing: The Long Interview Approach. In Stewart, M., Tudiver, F., Bass, M. J., Dunn, E. F., \& Norton, P. G. (Eds). Tools for Primary Care Research (3-30). Newbury Park: CA, SAGE.

51. Creswell, J. (2007). Qualitative Inquiry \& Research Design: Choosing Among. Five Approaches, 2 nd ed. California: Sage Publication.

52. Wilkinson and Birmingham. (2003). Using Research Instruments: A Guide for Researchers Master E-book ISBN. London: Routledge Falmer. 